
\title{
25 Research Suare \\ Multi-Project Model Program Runs With Algorithms to Improve Indian Coal Mining
}

Binay Kumar Samanta ( $D$ iitism.bks@outlook.com )

IIT (ISM): Indian Institute of Technology https://orcid.org/0000-0003-3322-1355

Dharavath Ramesh

IIT (ISM): Indian Institute of Technology

\section{Research}

Keywords: Algorithm, Program coding, Program runs, Database Models, Operating Return, Cost Benefit Analysis.

Posted Date: December 22nd, 2020

DOl: https://doi.org/10.21203/rs.3.rs-130977/v1

License: (1) This work is licensed under a Creative Commons Attribution 4.0 International License. Read Full License 


\section{Abstract}

Mining engineering is the most dangerous peace-time profession in the world. Primary Organization for coal mining in India is Coal India and extensive research has been conducted to improve performance. Development computerized methods emphasize better project scheduling, and converting scheduling and monitoring of a project in common package format for the multi-projects of a company The authors have also developed models for cost benefit analysis of improved systems of mining operations on ground realities and database models. The authors have developed for viable mining data-based computer methods in 14 original models, of which few are detailed for lack of space. India has 320 billion tonnes of coal reserve and it is 7 per cent of the reserve of the world. The energy consumption in India is about onethird of the world average and 60 per cent of installed capacity of energy in the country is based on thermal plants.

\section{Hightlights}

- 14 computer model programs, with run, accentuate better methods and they can be further modified in to software.

- Environmental Impact Analysis (EIA) and the Environment Management Plan (EMP), can be now processed simultaneously.

- Computerized development of database can help in financial resource planning for projects, as require high investment for high production mines for viability.

- Feasibility Report is recommended to have a Master Control Network, and update the network.

- Satellite transponder or microwave link up, as proposed in recommended to be implemented so that LAN and WAN techniques.

- The studies carried out should benefit mining industry by applying the results in improving performance of new and reorganized projects.

\section{Introduction}

Computer project software and developments have taken place for more than 330 versions. For success of multi-project, because of geological incongruence, every coalmine project should be critically analyzed for improvement. Around $87 \%$ of India's proven coal reserves total of 319.02 Billion tonnes estimated in the country as on 1.4.2018. Mine planning and project design is fundamentally dependent on geological attributes of the reserve. Most crucial problem is that mine reserves are widely varying and so project planning is unique for each mine and different. Comparatively industrial projects design can be implemented in any location on the parameters of equipment. Billions of (Rupees) are spent every year on mining and construction of projects spread all over India. Cost and time over runs of highly capita intensive projects can be checked and even $5 \%$ saving could mean millions of Rupees. 
Coal reserves are available in almost every country worldwide, with recoverable reserves in around 70 countries. The biggest reserves are in the USA, Russia, China and India. There are an estimated 1.1 trillion tonnes of proven coal reserves worldwide. In terms of coal production, total in the world is expected in 2019 is $7730 \mathrm{Mt}$, compared to $7,460.4 \mathrm{Mt}$ in 2016 . Country wise ranking with China \#1 is programmed to produce in $20193520 \mathrm{Mt}$ as against 3,411 Mt in 2016; India in \#2 position is expected to produce $716 \mathrm{Mt}$ compared to 692.4 Mt in 2016; USA in \#3 is planned to produce $702 \mathrm{Mt}$ as against $660.6 \mathrm{Mt}$ in 2016.

Major producers of coal in India are CIL subsidiaries and coal blocks allotted to private companies. Coal India Ltd is making profits from opencast mines mainly, overcoming the losses suffered by underground mines. Projects of costing above 5000 million ( $1 \$=71$ as in Sept 2019) are approved by the Govt. Remedial actions, wherever warranted are taken. Graphical Abstract shows Process of Approval Indian coal projects.

The researchers have developed his data-based computer methods in 14 original models. So, applying principles of Operations Research (OR), models have been designed, coded and run. The authors in due course have developed the following special model programs, shown in Table No-1, which can help proper planning, scheduling, monitoring and prioritization of coal projects.

\section{New Projects}

Since new mining projects are highly capital intensive, techno-commercial evaluation is necessary $[1,2,3]$ for the method to be adopted. So, recent advances in information technology has to be adopted $[5,7]$ for correct decision. The researcher has designed a small model program 'qep' based on Expert System (ES) concept and run it [19] with practical field and cost data. Project method A1 is for semi-mechanized Bord and Pillar system with tub loading and haulage. Project method A2 is for mechanized Bord and Pillar system with Side Discharge Loader (SDL) and chain conveyors. Project method A3 is for mechanized Longwall with Shearer, Armoured Face Conveyor (AFC), self-advancing hydraulic support etc. The objective is to develop right planning for scheduling and monitoring and it has been found from the output data of ES that cost increased with size of mine projects. Investment decision of projects [4] should be done on: -

i. Pay out time- i.e. when Break Even Point is reached, applied here.

ii. Average yearly payout- in terms of capital, works, crew, materials etc.

iii. Accounting Return or net profit on original investment- used in this ES, as main criterion.

iv. Operating Return- indicated in the ES annually.

v. Present worth of Cash flow discounted @10-20\%- used in the E.S for projection over 6 years.

vi. Net Profit- is computed excluding taxes and royalties.

vii. DCF Return- could be computed from the ES.

viii. Sensitivity Analysis- Change in output by change in input-indicated by higher BEP.

ix. Actuarial analysis for estimating service life for depreciation- in CIL for 9 years. 
x. Incremental cost analysis for marginal cost etc. - could be computed from the data generated.

Profitability Index (PI) or Return On Investment (ROI) or Discounted Cash Flow (DCF) rate of return are some [6] of the indicators of profits. ROI could be computed from: -

$\mathrm{ROI}=\mathrm{a}+(\mathrm{b}-\mathrm{a})\left\{\left(\mathrm{ar}_{\mathrm{r}}-1.0\right) /\left(\mathrm{a}_{\mathrm{r}}-\mathrm{b}_{\mathrm{r}}\right)\right\}=18 \%$ to $28 \%$;

Where, $a=$ initial rate of interest, $b=$ higher interest rate, $a_{r}$ or $b_{r}=$ discounted receipts $/$ discounted investment $=1.1$ to 1.2. ROE or Return on Equity is given by profit after Tax/ Net worth. Run of the program 'QEP' with actual data from mines show: -

1. In the program sample run, with available mine cost data, Longwall method has shown lower $A / C$ Return 10.75 and so ES has indicated as less suitable.

2. In favourable conditions, and if we standardize and indigenously manufacture LWPS, it could be the most [9] suitable method in future. IRR should be $12 \%$ at $85 \%$ production.

3. In order to achieve very high OMS and profitability, Continuous Miner technology with roof bolting could be adopted even in geologically disturbed areas.

4. A/C Return with SDL in B\&P method has come 14.93 and so the most suitable method in this study.

\section{Reorganized Projects}

In planning reorganized projects from old mines, crossing Break Even Point (BEP) level of production is essential. The researcher has developed 2 Database model programs, 'bep' for Recalculating BEP, reducing Variable Cost and 'bep2' for Revised BEP, on Additional. Investment for making an old mine viable. Data were compiled from the cost sheets submitted by the collieries of a company in 3 different months. Since, fixed costs and variable costs are not indicated so they are computed and entered in the records. Profit/loss and fixed cost was computed by:-

PROF_LOS = SAL_PRIC-NET_COS

FIX_COS = NET_COS-VAR_COS+

BRK_EVN_PT = FIX_COS*PR_TPD/(SAL_PRIC-VAR_COS)

If BEP could not be achieved without additional production from mechanization, needing additional investment for the additional production, total BEP changes: -.

TOT_BEP = BRK_EVN_PT+ADL_PROD

It is assumed that $22 \%$ of the annual depreciation + interest and 300 is number of working days in a year. It can be found that additional investment of 1 million could be neutralized with additional 2 tpd, e.g. as in the PDV_PDV mine. However, this additional investment and ADDL_PROD required would be higher accordingly. Again, the program computed revised total break-even point [15] of the colliery. Once, the 
techno-economics of coalmine Reorganization Project is finalized, viz. programs runs, scheduling of activities and monitoring for completion become valuable

\section{Coal Multi-projects}

System approach is required for planning $[8,11,13,14]$ projects, scheduling and controlling. Since, coal mining project activities are differing widely, yet they are grouped in standard packages. All the packages are further divided into sub-packages and totaling is made head-wise, applicable for all types of mining, in conformity of budget heads. The model program ' $m p s$ ' for computing the entries of a single project and model program 'mpt' for different projects of a company in a particular month, with budget vs. actual and \%schedule vs. \%progress for monthly monitoring. It has included import java.io.*; basic input/ output system header file, java.lang.*; javax.swing.*; java.awt.*; import java.util.* also. Combining clearly different activities in to common packages and running mps for individual projects $[17,19,25]$ and then feeding them in to mpt and yielding company-wise output for any month.

\section{Cost Benefit For Scheduling}

Improvement of methods and systems, could plan better projects $[13,23,25]$ to schedule and monitor. Cost Benefit Analysis before planning, specially new and emerging methods can make successful projects.

5.1 Shaft lining - Indian coal reserves are mostly in hard sedimentary rocks, and mine pits used to be lined only upto rock head. Now, legislation demands lining of shafts and method of monolithic lining has become very costly and so cheaper possibility of shotcrete lining has been examined. The model program run of 'scl' makes some projections and coded in this program are 'netsave'- expected net saving, 'conlicst'- saving in concrete lining cost, 'exvcst'- saving in excavation cost, 'wincst' - saving in winch and shuttering cost, 'slcst'- shotcrete lining cost, 'diam'- diameter of the finished shaft, 'depth'- of the shaft in $m$ etc. By realistic input of data, a sample program run with different diameters and depths showing the cost benefit by applying shotcrete lining compared to monolithic concrete lining is determined. Figure-1 displays the flowchart of program for cost benefit by shotcrete shaft lining. Table- 2 displays the benefits by program run.

5.2 Improved Track and Support - Most traditional underground mines have track haulage as the main coal production transport system. So, in planning and scheduling better track system for coal transportation is essential $[14,26]$. Model program 'stl' determines the cost benefit and accordingly scheduling and prioritization of mines for implementation. It could be observed from the program run that projected cost saving by adopting steel sleeper was quite considerable and the savings ranged from 1.2 to 4.9 million per year.

The 'stl' model program writes the data according to format statement, like column-colliery, name, TYPtype, NTS- no. of timber sleeper, DCOST- dog nail cost, NSS-no. of steel sleepers $=80 \%$ NTS, as life could 
be 20 years against 4 years of timber found; YRPR-yearly production, and CP-coal price. Then, assignment statement, TC-timber-track cost, SC-steel track cost, type ' $*$ '-metre gauge, TTC-total timbertrack cost, DSAV- derailment saving, and CB-cost benefits etc. are coded in the program. It has been established by the computer program run, that although the price of timber sleeper is $1 / 5$ th of the steel sleeper, in the long run the designed steel sleeper can yield annual saving with less derailment.

Figure No-2 shows program flowchart for coal projects package-wise and month-wise.

5.3 Strata Control Cost Benefit Among the various methods of stowing for filling voids after extraction of coal, sand stowing is the most prevalent, as compared to costlier crushed stone, pneumatic or high speed belt stowing, etc. So, sand separation from hydraulic transportation by dredging of dam reservoir has been examined [31,36]. On approximate capital cost for pumps and pipelines, used in the computer program run, the coded 'dre' show great benefit. Actual gain in saving in hydel generation would be more, as the reservoir is replenished with water after evacuation of sand.

Most of the recent capacity slurry pipelines utilize Centrifugal type pumps, capable of transporting large size lumps up to 4" size. These pipelines show pronounced savings, compared to conventional systems of transport. Discounting all savings in flood control, power generation and truck transport, the cost per $\mathrm{m}^{3}$ of sand worked out by computer simulation to $10-17 / \mathrm{m}^{3}$ at peak capacity of pipelines.

5.4 Quarry Planning Cost Benefit \& Scheduling - Most opencast mines or quarries practice transportation of coal and overburden by circuitous haul roads, very costly to maintain. So, steep transport method has examined directly to surface bunker $[14,21]$ has been studied. When the model program 'troq' was compiled and run, with layout of crusher, bucket elevator and bunker with screen for steam and slack coal. The program run output, shows accrued saving ranged from Rs.40.10/t, in RJ-RJM mine to Rs.1175.62/t in MU-SHP mine. The fact stands out that there is considerable justification in reorganization to electricity driven vertical transport in opencast mines, especially small mines. There will be greater utilization of shovels, especially in small quarries. Surplus dumpers and trucks could be shifted to new or other mines resulting in more production. There should be more OB removal, as haul roads would be solely used for the purpose. Figure- 3 shows the flowchart of computations of cost benefit by steep transport in quarries.

5.5 Underground Machinery Cost Benefit \& Scheduling - There are various types of underground mining machinery $[9,30,33]$ available and so according to the particular mine reserve geology, database program has been coded and run. The model program 'eqp' has considered 4 types of equipment packages, most commonly used in Indian coalmines, namely Side Discharge Loader (ESDL), Load Haul Dumper (ELHD), Continuous Miner (ECHMN) and Longwall Shearer with Power Support (ELWPS). Here, prefix E stands for equipment set, for the type of face. The variable names have been declared with codes and data types-namely SLNO, COLLIERY, COE (Cost of Equipment), POC (Production of Coal/y), DIT (Depreciation and Interest), PMT (Power \& Maintenance), SC (Store Cost), WC (Wage Cost), OC (Other Cost), PC (Production Cost), CP (Cost of Production), and CB (Cost Benefit in Rs./t). The cost of 
equipment have been shown with switchgears and declared in DATA statement, in Rs. Millions - ACNV (Armored Conveyor), BCNV (Belt Conveyor), CCNV (Chain Conveyor), SDL, LHD, CNMN (Continuous Miner) and LWPS. The input data file has been named eqp.dat and its header is formatted, as per statement 5.The Run file is named eqp.txt and the header is formatted as per statement 10.

The program is designed with a subroutine for selecting Equipment Type, with input of Shear Strength of roof stone (SSR), coal (SSC), floor stone (SSF), seam thickness (CST), largest faultless panel (LFP) etc. EQTYP selection has been based on the parameters in the program. EQTYP=ELWPS if LFP $>100$ Hectares and SSR $<100$ bar; $=E C N M N$ if SSC $<20$ and LFP $>50 ;=E L H D$ if $C S T>5$ and SSF $>80 ;=E S D L$ if $C S T<4$ and SSF $>100$. Pre-Feasibility Report can be made using the model 'eqp' to select appropriate equipment set. Figure-4 shows the flowchart of program for selection of underground mining equipment.

\section{Scheduling \& Monitoring Models}

When cost benefit analysis is encouraging by designed program run with realistic data for a new or reorganized method, then planning for scheduling is logical next step. Coal mine project construction is highly capital-intensive; funding requirement is very often changing for geological and techno-economic reasons.

6.1 Opencast Coal Mine Project Monitoring - Computerized AON PERT diagram, created on a computer by the set of input data of a large project. The activity name is followed by duration in brackets, e.g. coal production sec-A. Since, the project has been rescheduled, there was very little float, found in the chart. The critical activities, is shown by bold lines, on the bar chart, as computed by the compiler. New techniques were applied by the researcher for numerous advantages of reviewing computerized networks, after the first input of data. Review could be done any date, provided all data of revision or reschedule of activities. Activities could be split, deleted, inserted or even relocated with change of dependencies, with change of start dates and resources, the compiler automatically computes, all remaining parameters of the network.

6.2 Underground Coal Project Monitoring-According to the above system of packages, a project network of an underground mine of ECL, codenamed SAT, was computerized. The project was designed to produce $1.2 \mathrm{Mt}$ of coal per year. 2 new shafts, $7.2 \mathrm{~m} \Phi$ had been sunk up to Dissergarh seam in the first phase and were being equipped. A pair of inclines was to driven to Dissergarh seam also to work the seam in the rise area.

Project completion time-TMIN, COUT(J) set to 0, incremented by 1.Similarly, ES-early start, EF-early finish, LS-late start, LF-Late Finish, EN and LN-early or late completion of node, with dates [14,34]. In Forward Pass, all activities are to be computed from node 1 till completion. $F F(i)=0+T(i), L S(J)=L F(J 0-T(J)$. In Backward Pass, latest node time is set equal to project completion time, starting from last node. $\mathrm{LN}(\mathrm{M})$ $=\mathrm{TMIN}=\mathrm{EN}(\mathrm{M})$. CPM is applied, when time schedules are worked out to determine critical path and rescheduling. 
6.4 Capital Budget Monitoring-Because of geo-mining problems, rescheduling has to be resorted to very often and adjusting fund scheduling. Resource allocation $[13,28]$ as per schedule is essential, like men, money, machinery and materials of which money is the most important, as it can arrange other resources. The spreadsheet columns and rows are required to be updated every month, a model 'macro' program has been designed by the researcher for automatic cursor movement, for input of data, saving and printing. Moreover, in the spreadsheet, cell formulae have been incorporated for automatic computing of the assigned variable, totals etc. Computing monthly financial scheduling, showing the columns that need not be changed every month of all projects of a company. In multi-project financial allocation, as per priority of projects and criticality of activities some re-allocation of budget between different heads and projects has to be made with joint meetings and exigencies of the situation.

6.5 Coal Projects Responsibility Scheduling - Main Purpose is to ensure achievement of targeted schedules, within budgeted cost and manpower, by solving day-to-day problems of responsibility scheduling $[22,36]$. Thus, a model program ' $m b$ ' is created, for specific purpose, here for charting the key tasks for different management positions according to conditions in the coalmine project. Decision Chart and the query based computer program is able to produce a revised Decision Chart, of any month for any project. On detail studies, outcome of this process to standardize coal project 24 key tasks against 13 different management positions in coal industry.

Job Effectiveness Description JED of a mine Project Manager, developed by the researcher, shows Program Run of mbo.java for a Particular Project for the Review Month. The executives in green colored boxes should actively cooperate for the key task area shown, those in yellow color to help whenever required and those in red color need not bother for this key task and concentrate on their routine duties.

If the coalmine project officials are not responsive to the changing situations, and stick to routine duties, the project would suffer and so there is need for responsibility scheduling. Objective Setting by Action Plan, Responsibility scheduling with Decision Chart by Confidence Factor CF and and sample run mbo.bat displays for a particular project for certain month. Figure- 5 shows the flowchart executive manpower scheduling. Figure-8 shows model run of the program for different key tasks. Figure-6 displays Model Run of the Program for Different Key Tasks for different executive positions.

6.5 Crisis Management Scheduling - Quick scheduling of activities is very important in any disaster or crisis on [27] strategies with allocation of responsibilities by phone, wireless etc. Coal mining is very disaster-prone and numerous catastrophes have taken place owing to fire, explosion, inundation, roof-fall etc. in which many employees lost their lives. Disaster struck at Mahabir Colliery, west of Raniganj town of ECL, a subsidiary of CIL on 13th Nov'89 at 4 AM, when there was sudden inrush of water from old workings of upper Nega (R-VIII) seam to working Narainkuri (R-VII) seam. Water swirled down inundating the pit-bottom of the working pits $A \& B$ and lower workings of the mine. Mahabir capsule rescue is still a world record of its type, 65 employees in 4 days, in contrast to rescue of the 33 miners trapped deep underground for 69 days, in mine in Chile, who got trapped on 5 August and brought up on 14 October 2010. 
In model program 'dew' inputs of STAT_VOL (Static volume of water underground), SEPG_WAT (Make of water), DEW_RAT (Dewatering rate), FLB_RAT (into the mine through surface fissures), are made for computing DEW_TIME in days (for dewatering). Sample run of the model program, with incremental dewatering and flow-back rates of water was done. Although, 59 survivors were rescued on $3^{\text {rd }}$ day, but ALT_NO 10 in the program run came close to reality, when after about a month, 6 dead bodies were recovered. This is a unique world-record making disaster management scheduling work, in which the researcher had played a key role. The researcher's contribution was acclaimed by international journals like Reader's Digest, June '91 issue in English, Oct '91 issue in Hindi, January'92 issue in Dutch and in many other language editions.

\section{Conclusions}

The researcher has analyzed the results of hundreds of World Bank aided projects, indicating that success or failure often depend upon factors outside the control of Project Manager. The management of projects has to depend upon many other external agencies, like Govt - Central \& State, Contractors, suppliers, service engineers of equipment etc. During implementation of projects the following problems are faced during monitoring and control: -

1. Master Control Network originally approved by ministry, has to be revised for various reasons, delays, failures etc.

2. Monitoring packages, sub-packages and activity is not done properly at the project level normally, like start date, completion date, duration, resourced need, slippage, reasons for slippage, responsibility, physical and financial provision of critical activities required to overcome time and cost overrun.

3. Computerized methods in model programs developed by the researcher can be very useful for right planning, scheduling monitoring \& prioritization of Indian coal mining projects.

4. Computerized development of database can help in financial resource planning for projects. Private companies allotted with 289 coal blocks can take advantages. Coalmine projects require high investment and the world trend for high production mines for viability is noticeable.

5. Recent trend in computer networks is replacement of Activity on Arrow (AOA) networks by Activity on Node (AON) networks or Precedence type.

6. Proper monitoring is the key to successful project, as it helps to determine critical path, quicker completion of activities on it by crashing, reallocation of resources and minimize time overruns, which in turn also control cost overruns.

7. Both hardware and software compatibility is required between CIL and its subsidiaries, so that any project network can be interfaced with COALNET intranet, through communication software, in which Project monitoring is also included.

8. Satellite transponder or microwave link up, as proposed in recommended to be implemented so that LAN and WAN techniques are used by COALNET to link up projects and to subsidiaries of Coal India. 
9. The computer model studies carried out should benefit mining industry by applying the results in improving performance of new and reorganized projects.

Developed model programs by the researchers by method and time studies for planning, scheduling and monitoring can yield successful projects and prioritize multi-projects. COALNET approved by ministry should be made more effective.

\section{Declarations}

Conflict of Interest: Corresponding Author is a part-time researcher with IIT(ISM), Dhanbad with academic help only and there is no conflict of interest. I have no relative who works at the company whose product the researcher is evaluating or A self-serving stake in the research results (e.g. potential promotion/career advancement based on outcomes), as I am part-time Researcher.

Ethical Statement: Originality of research is the priority and of course I have included references of help and updates from latest research.

Funding Body: No official funding was allocated by IIT(ISM) or Project \& Environment Consultants, help for study was given by ECL, while I was working as General Manager, Eastern Coalfields Ltd, a subsidiary of Coal India Ltd.

\section{ACKNOWLEDGEMENT}

Gratitude is expressed to Computer Science \& Engineering Deapartment of IIT(ISM), mainly Dr. C.J.Kumar, Professor and former HOD(CSE), Dr. G.P.Biswas former HOD (ESE) and Dr. R,M.Bhattacharjee, HOD(ME). The authors are thankful to Dr. D. C. Panigrahi, former Director IIT(ISM) for the suggestions towards improvement of the quality of paper. Gratitude is expressed to Dr. Rajiv Shekhar, Director, IIT(ISM), numerous friends and colleagues. Thanks expressed to Dr. D.K.Sinha, Former Director ISM my former Phd Guide and also Dr.A.B.Samaddar former Director, PDSIT, BESU.

\section{References}

1. Adami, V. S., \& Verschoore, J. R. (2018). Implications of network relations for the governance of complex projects. Project Management Journal, 49(2), 71-88.

2. Anderson D \& Verna A (2005): Project Management is a capital investment process; Journal of Management \& Engineers, Oct 2005, Vol.24, No.4, - ISS0742-597X

3. Arora, Rajesh (2010): Techno-Commercial Evaluation of Coal Mining Project; 3rd Asian Mining Congress, 22 - 25 January 2010, Kolkata, India, The Mining, Geological and Metallurgical Institute of India (MGMI).

4. Banerjee, S.P (2012): Some Thoughts on Capacity Building for Sustainable Development in Indian Mining Sector; $4^{\text {th }}$ Asian Mining Congress, 29-31 January 2012, Kolkata, India: The Mining, 
Geological and Metallurgical Institute of India (MGMI).

5. Bhattacharya Jayanta (2017); Global Financing Methods Of Mining Projects and Evolution Of Alternative Finance; 7th Asian Mining Congress 2017; Kolkata 8-11 November 2017

6. Kumar Chiranjeev, Banka Haider \& Ramesh Dharavath (2016): Recent Advances in Information Technology, (Proceedings of the 3rd IEEE International Conference RAIT-2016, March 03-05, 2016, Vol. I \& II, ISM, Dhanbad, India), 2016, ISBN: 978-1-4799-8578-4

7. Dinsmore Paul C. and Cabanis-Brewin Jeannette (2009): AMA Handbook of Project Management; J Knutson, I Bitz - Amacom, New York, 1991 USA

8. Garg, V.K and Bhabani, K (2001): ERP based Reengineering of Management Systems; Industrial Engineering Journal, Vol.XXX, Mumbai.

9. Gopalakrishnan, P and Ramamurthy, V.E (2001): Textbook on Project Management; McMillan India Ltd, New Delhi.

10. Grete Hagebakken, Trude Høgvold Olsen and Elsa Solstad (2020): Success or failure? Making sense of outcomes in a public sector change project, Journal of Management \& Organization, ISSN: 18333672; DOl:https://doi.org/10.1017/jmo.2020.19

11. Guo H, Zhu K, Ding C, Li L (2010): Intelligent Optimization for Project Scheduling of the First Mining Face in Coal Mining; Expert Systems with Applications: An International Journal, Volume 37, Issue 2Pergamon Press, New York.

12. Kumar Brajesh (2017): E-Capital Fund Management Including Re-Appropriation; 7th Asian Mining Congress 2017; Kolkata 8-11 November 2017

13. Kerzner, Harold (2009): Project Management: A Systems Approach to Planning, Scheduling, and Controlling; - Amazon.com

14. Mahadevan, Ashok (Nov'90 and June'91): Readers Digest; RDI Publishing Co, Bombay.

15. Mitchell, Paul (2011): Achieving Major Capital Project Effectiveness and Corporate Performance; Effective Capital Project Execution Mining and Metals, Ernst \& Young, (c) 2011 EYGM Limited. Australia.

16. Müller, R., \& Lecoeuvre, L. (2014). Operationalizing governance categories of projects. International Journal of Project Management, 32(8), 1346-1357.

17. Noort, D J and Adams, C (2006): Effective Mining Project Management Systems; International Mine Management Conference, Melbourne, Vic, 16 - 18 October 2006.

18. Pemsel, S., Wiewiora, A., Müller, R., Aubry, M., \& Brown, K. (2014). A conceptualization of knowledge governance in project-based organizations. International Journal of Project Management, 32(8), 1411-1422.

19. Samanta, B.K.(1996): Break-Even Point Monitoring of Collieries with Database Programming; Minetech Vol.17, No.5, pp.34-37, Sept-Oct.1996.

20. Samanta, B.K.(1996): Coal Face Mechanization Selection and Scheduling with a Computer Program in FORTRAN; Minetech, Vol.16, No. 1 \& 2, pp 34-43, Jan-Apl'96. 
21. Samanta, B.K.(1998): Computerized Coal Multi-project Monitoring; Minetech, Vol. 19, No.6, NovDec.'98.- CMPDI, Ranchi.

22. Samanta, B.K. (1990): Quick Evaluation of Projects by Computer Programming; Seminar on Computer Application in Mining Industry - Institution of Engineers, Asansol Center.

23. Samanta, B.K. \& Samaddar, Dr. A. B. (2002): Formulation of Coal Mining Projects by Expert System; pp202- Journal of Mines, Metals and Fuels, ISSN 0022-2755, June 2002, Kolkata.

24. Samanta, B.K. (2002): Coalnet-A Developing Intranet; XXXVII National Convention 2002 of Computer Society of India, October $29^{\text {th }}$ to $31^{\text {st }} 2002$, Bangalore, India.No.42, pp251- Tata McGraw-Hill Publishing Company Limited, New Delhi.

25. Samanta, B.K. (2003): IT Applications in Reorganization of Quarries; RIT 2003- National Seminar on Role of IT in the Present Scenario of Globalization, CMRI \& CSI- 1-2 February, Dhanbad.

26. Samanta, B.K (2005): Mine Project Responsibility Scheduling; International Symposium on Advances in Mining Technology and Management; IIT, Kharagpur, Nov 30- Dec 2; 2005

27. Samanta, B.K (2006): Advances in Computerized Project Scheduling \& Monitoring; All India Seminar on Advances in Computer and Information Technology- IE(I), Dhanbad Chapter, ISM GJ Auditorium, 11-12 March, 2006.

28. Samanta, B.K (2007): Emerging Computerized Project Scheduling Networks; Recent Advances on Information Technology (RAIT-2007); Proceedings of the National Seminar, Allied Publishers Pvt. LtdDepartment of Computer Science \& Engineering; Indian School of Mines University, Dhanbad-826004, Feb 26-27, 2007.

29. Samanta, B.K (2012): Developments in Computerized Multi-Project Management for Sustainable Mining; $4^{\text {th }}$ Asian Mining Congress, Sustainable Mining in Asia - Challenges and Opportunities, The Mining, Geological, \& Metallurgical Institute of India (MGMI), 29-31 January, 2012, Kolkata.

30. Samanta, B.K (2012): Mining Multi-Project Monitoring Computer Model for Summarized Assessment; National Convention of Mining Engineering of IE(I), Kolkata in collaboration with BESU; 23-24 Feb' 2012.

31. Samanta, B.K (2017): Multi Criteria Decision Model for Mining Projects; Journal of Modern Project Management, www.com/; Google Scholar Citation, January-April 2017; pp.113.

32. Samanta, B.K (2017): Strategies to Achieve National Demand of Coal and Mineral Production; The Indian Mining \& Engineering Journal, com/ January 2017.

33. Samanta, B.K (2017): Coal Project Responsibility Scheduling Model, International Journal of Engineering Trends and Technology (IJETT), V44(4),146-152 February 2017. ISSN:2231-5381. www.ijettjournal.org. published on peer review; Thomson Reuters affiliated.

34. Samanta, B.K (2017): Underground Mining Project Equipment Selection Model, International Journal of Computer Trends and Technology (IJCTT) V44(1):50-57, February 2017. ISSN:2231-2803. www.ijcttjournal.org. Published by peer review; Thomson Reuters affiliated. 
35. Samanta, B.K (2018): Programming for sustainable mining projects; Journal of Mines, Metals \& Fuels; ISSN 0022-2755; Vol.66, No.3, March 2018, pp203. ( (Scopus indexed)

36. Samanta, B.K (2018): Scientific Research for Earthquake Proof Support for Underground; International Journal of Scientific \& Engineering Research; ISSN 2229-5518, Volume 9, Issue 5, May2018, pp 67. (Peer Review)

37. Samanta, B.K \& Samaddar B (2017): Underground Mining Slurry Transportation Viability; International Journal of Coal Science \& Technology; (peer-reviewed), 30 May 2019, https://doi.org/10.1007/s40789-019-0257-2, Springer

38. Sommerville lan (2001): Software Engineering; Addison-Wesley Longman (Singapore (P) Ltd., Delhi.

39. Tsaturyan, T., \& Müller, R. (2015). Integration and governance of multiple project management offices (PMOs) at large organizations. International Journal of Project Management, 33(5), 1098-1110.

40. Zwikael, O., \& Smyrk, J. (2015). Project governance: Balancing control and trust in dealing with risk. International Journal of Project Management, 33(4), 852-862.

41. Project Management https://technology.infomine.com/ProjectManagement/

42. Coal Mining Projects https://www.fluor.com/projects

43. Coal Mining Policy and Major Initiatives https://www.coal.nic.in/sites/upload_files/coal/files/coalupload/xchap4.pdf

\section{Tables}

TABLE NO-1: LIST OF COMPUTER MODEL PROGRAMS AND RUNS 


\begin{tabular}{|lll|}
\hline SN & Chapter/Model & Purpose of Model Program \\
\hline 1 & $3.1 /$ qep & Quick Evaluation of Projects \\
\hline 2 & $3.2 /$ bep & Recalculating BEP, reducing Var. Cost \\
\hline 3 & $3.2 /$ bep2 & Revised BEP, on Additional. Investment \\
\hline 4 & $4 /$ mps & Single Project Scheduling Package-Wise \\
\hline 5 & $4 /$ mpt & Multi-Project Scheduling for Company \\
\hline 6 & $5.1 /$ scl & Cost-benefit of Shotcrete Lining in Shafts \\
\hline 7 & $5.2 /$ stl & Cost-benefit of Track Steel/RCC Sleepers \\
\hline 8 & $5.3 /$ dre & Cost-benefit in Dam Dredging for Stowing \\
\hline 9 & $5.4 /$ troq & Opencast Mine Transport Reorganization \\
\hline 10 & $5.5 /$ eqp & Selection of U/G Equipment \& Scheduling \\
\hline 11 & $6.2 /$ snet & Simulation of PERT for Mine Project Scheduling \\
\hline 12 & $6.3 /$ fecl & Macros for Updating Financial Scheduling \\
\hline 13 & $6.4 /$ mbo & Key task against Management Positions \\
\hline 14 & $6.5 /$ dew & Computing. Dewatering Time of a Mine \\
\hline
\end{tabular}

Due to technical limitations, table 2 is only available as a download in the Supplemental Files section.

\section{Figures}




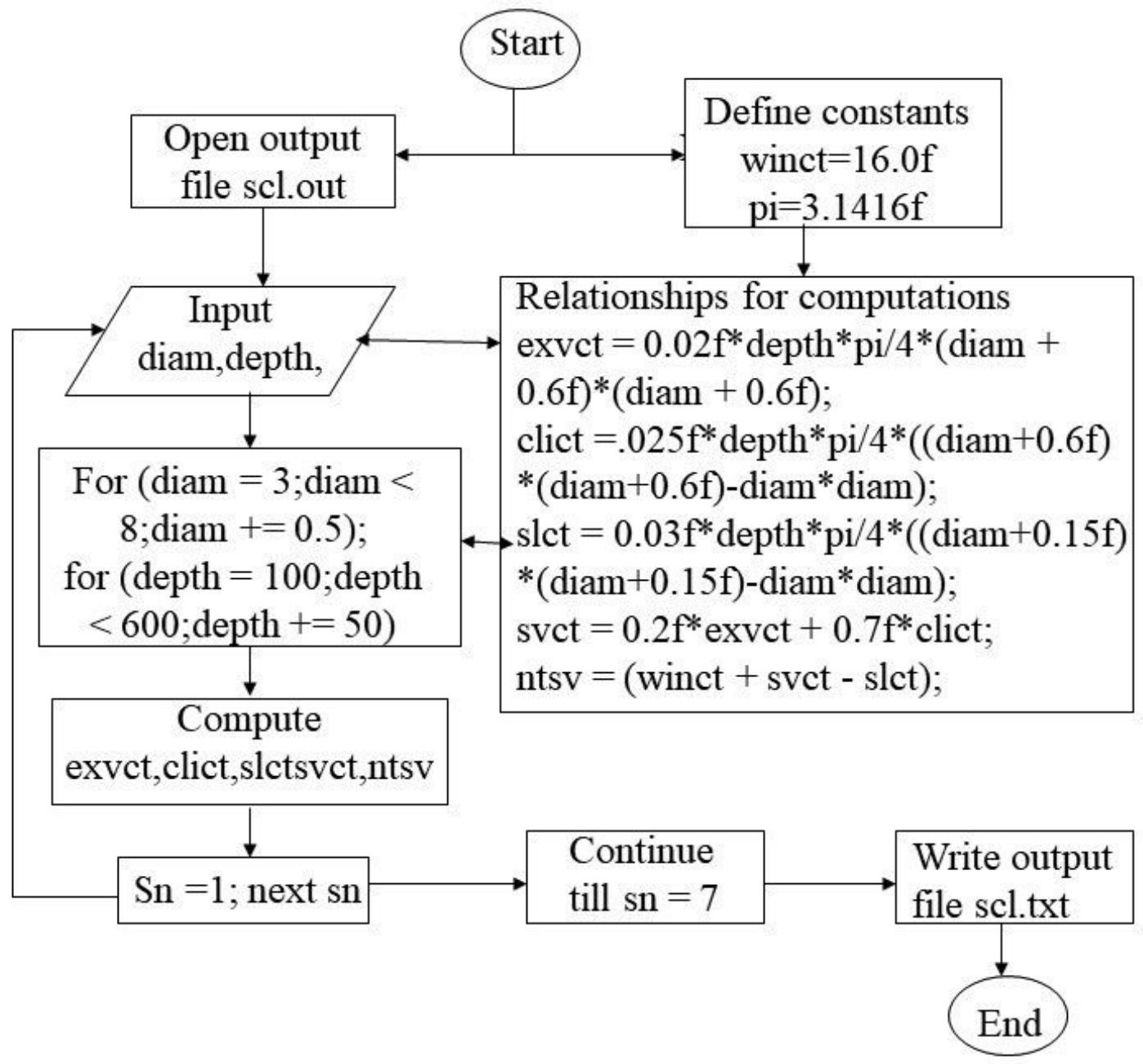

Figure 1

displays the flowchart of program for cost benefit by shotcrete shaft lining. Table- 2 displays the benefits by program run. 


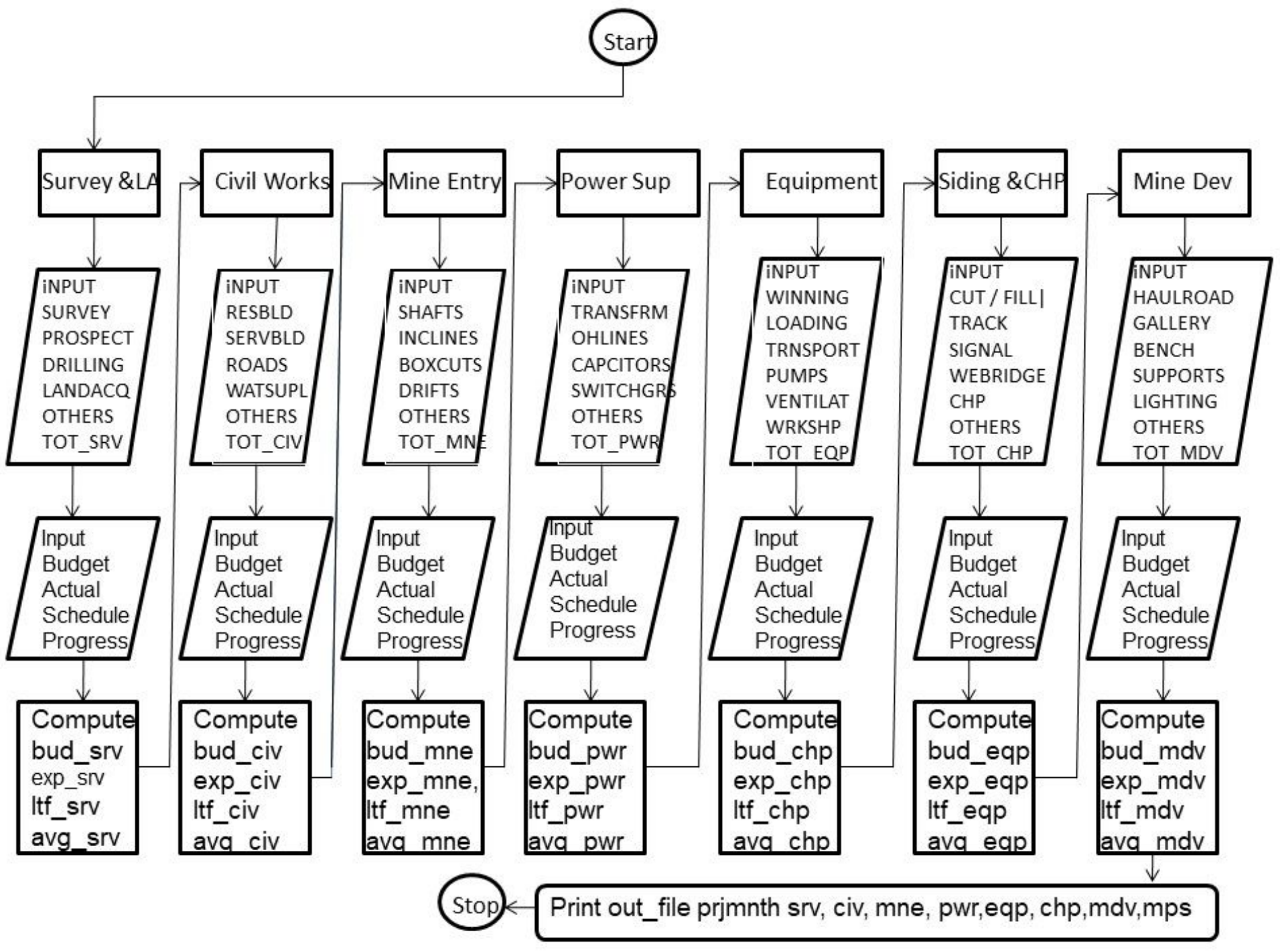

Figure 2

shows program flowchart for coal projects package-wise and month-wise. 


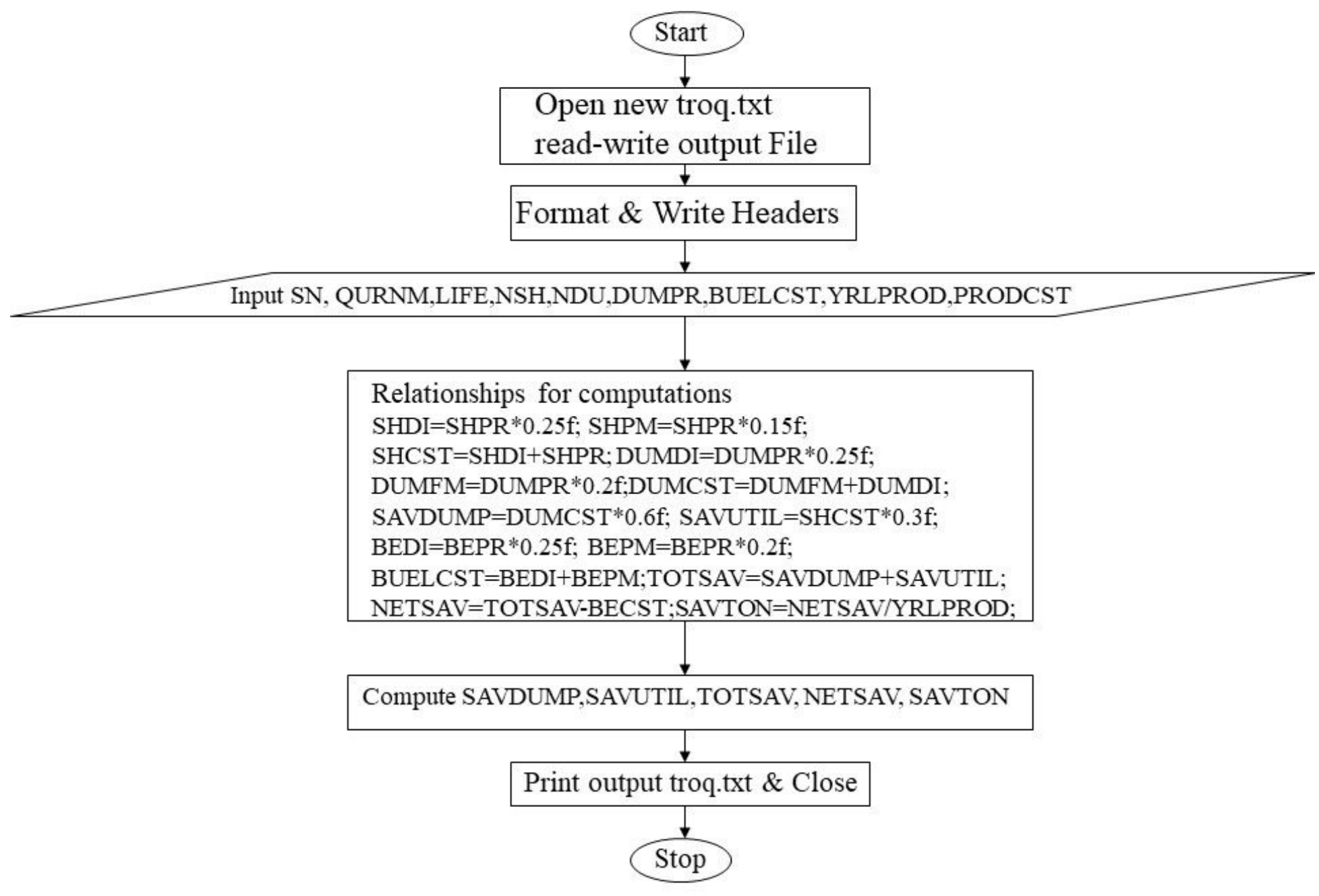

Figure 3

shows the flowchart of computations of cost benefit by steep transport in quarries. 
FIGURE NO- 5.41

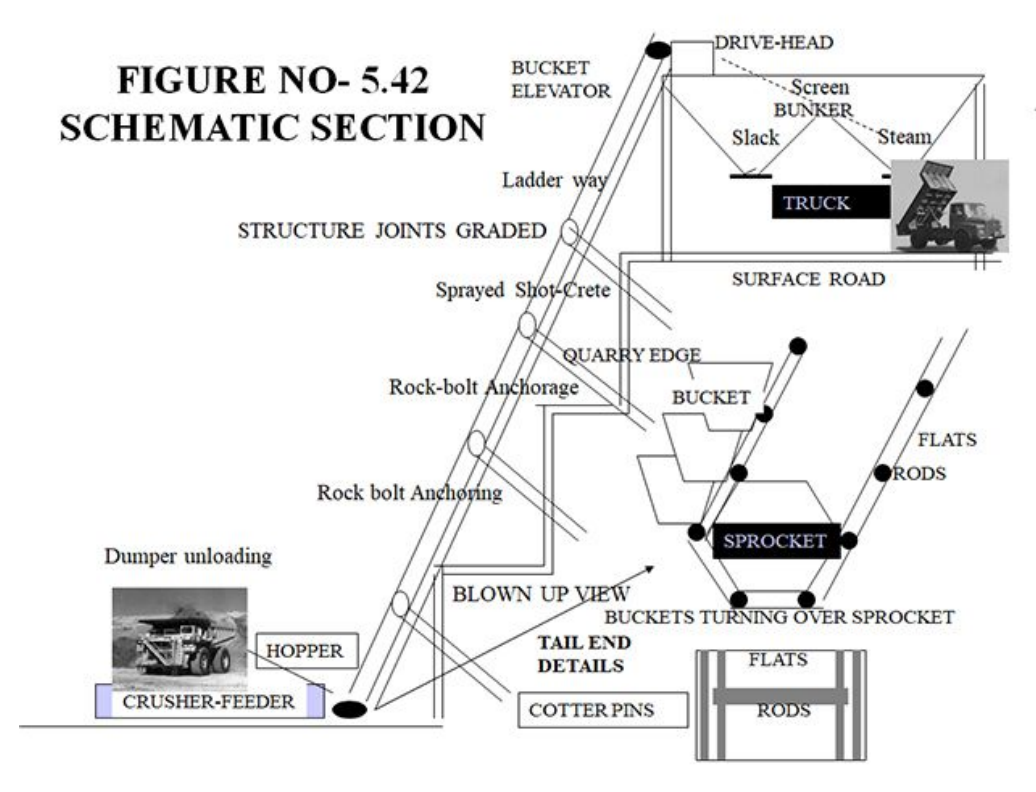

\section{SCHEMATIC SECTION}

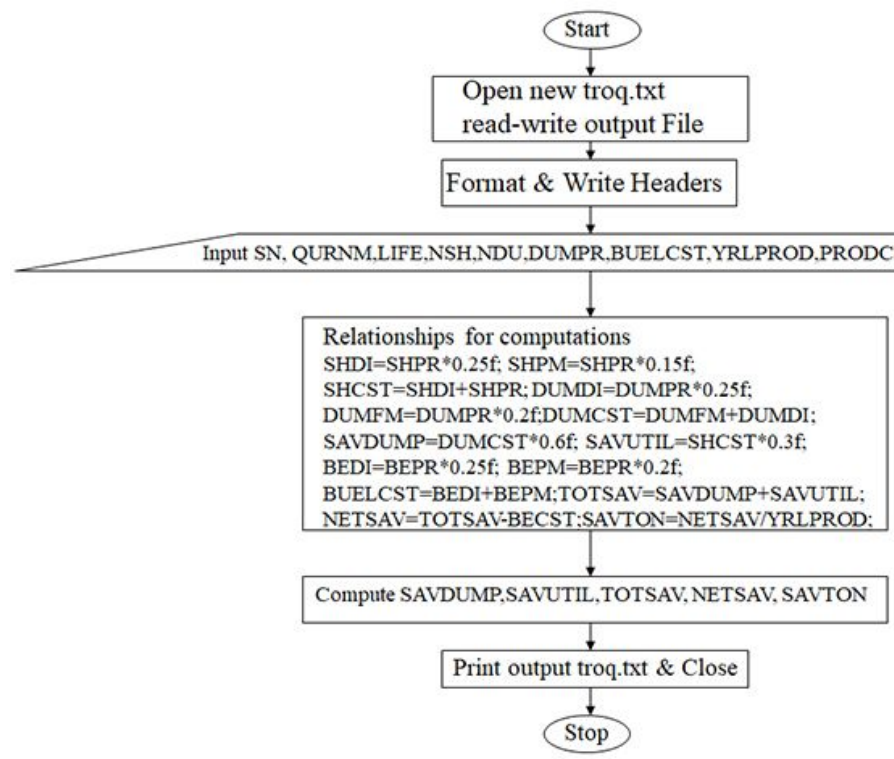

SCHEMATIC LAYOUTOF REORGANISED QUARRY
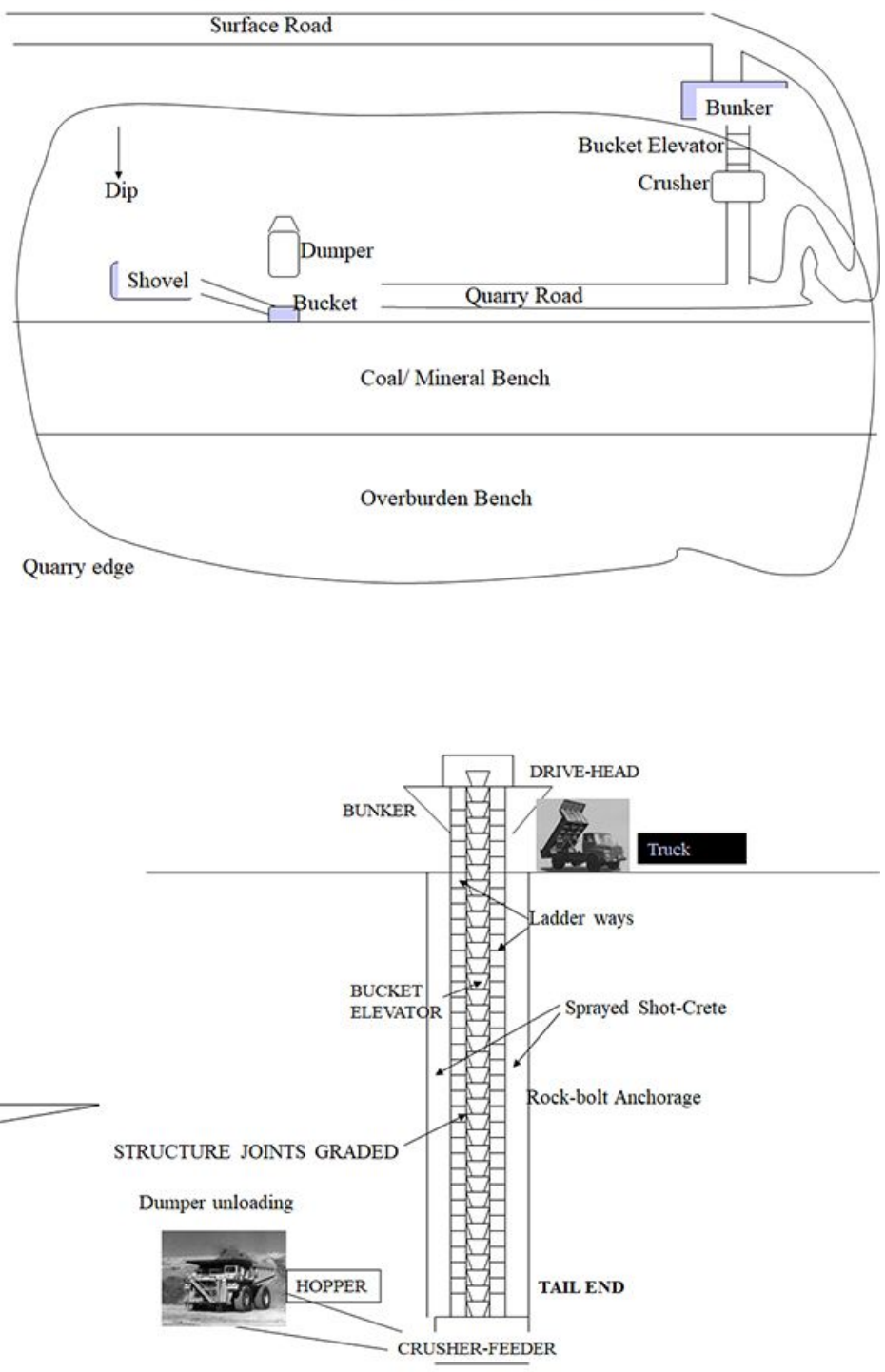

FIGURE-5.44 FRONTAL VIEW OF INSTALLATION

\section{Figure 4}

shows the flowchart of program for selection of underground mining equipment. 


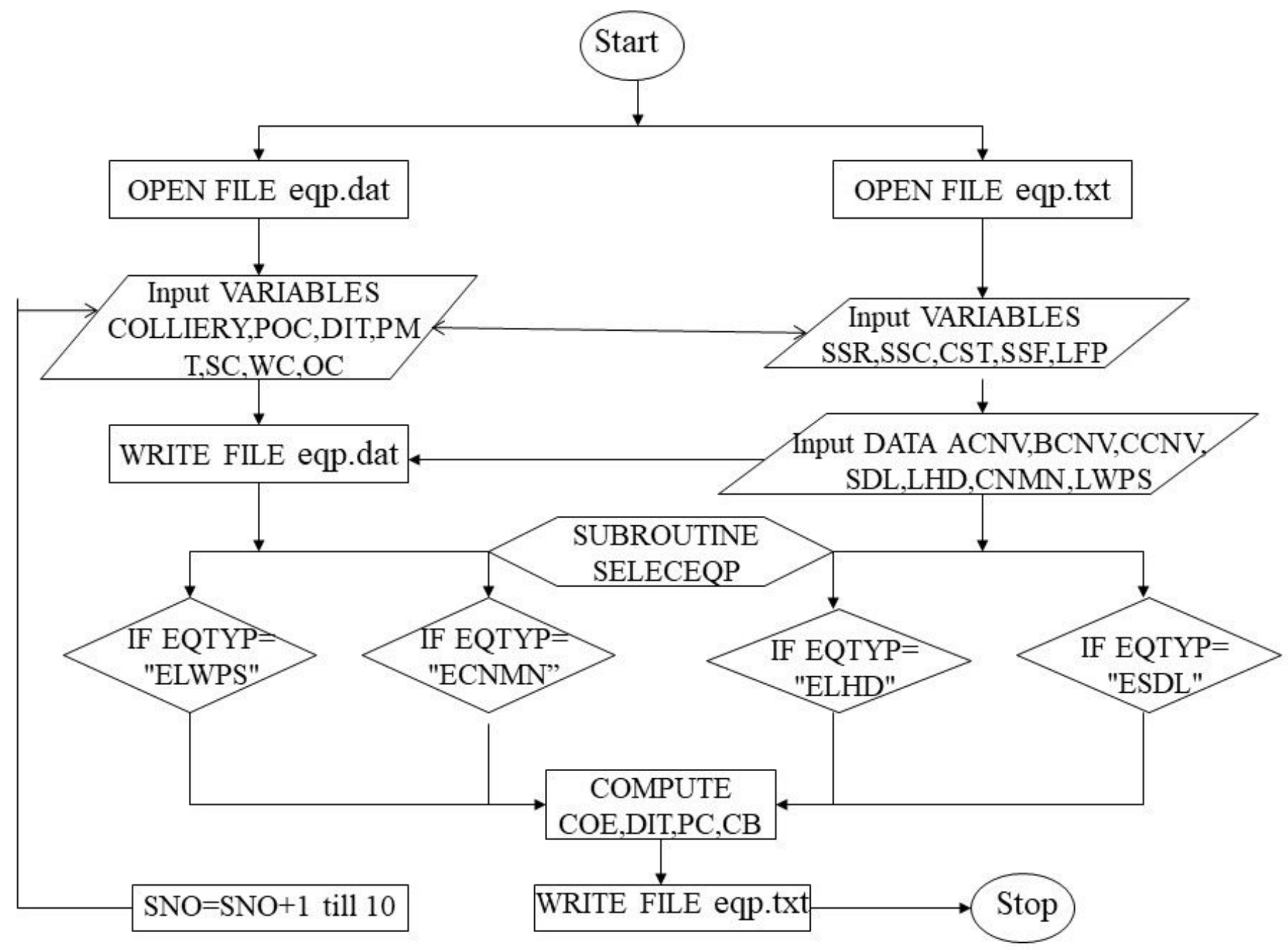

Figure 5

shows the flowchart executive manpower scheduling. 


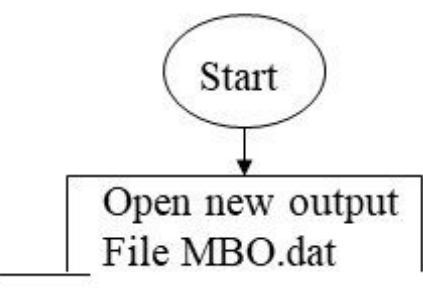

\section{FIGURE NO- 1}

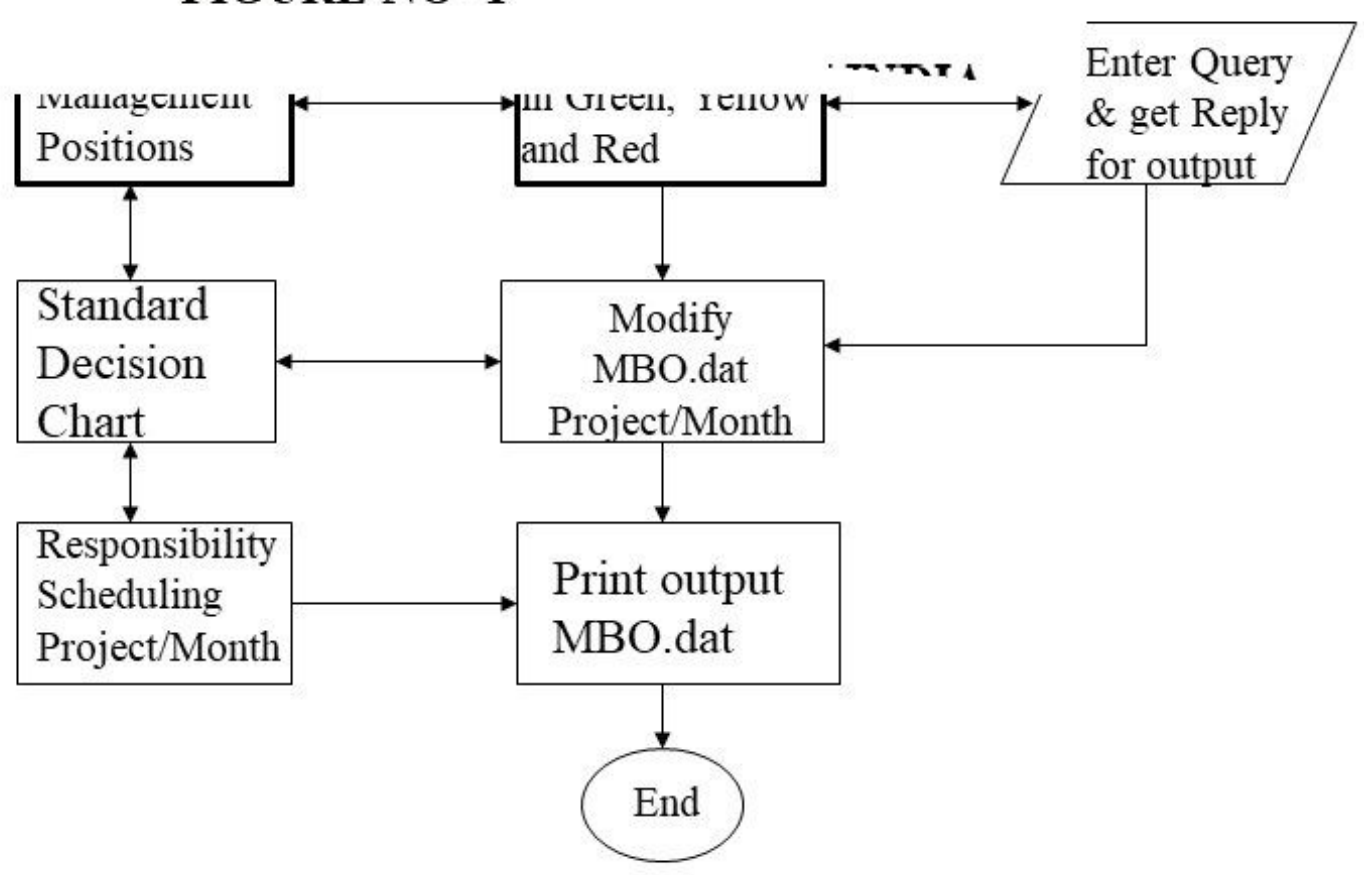

\section{FIGURE NO- 6 : FLOWCHART OF RESPONSIBILITY SCHEDULING}

\section{Figure 6}

displays Model Run of the Program for Different Key Tasks for different executive positions. 


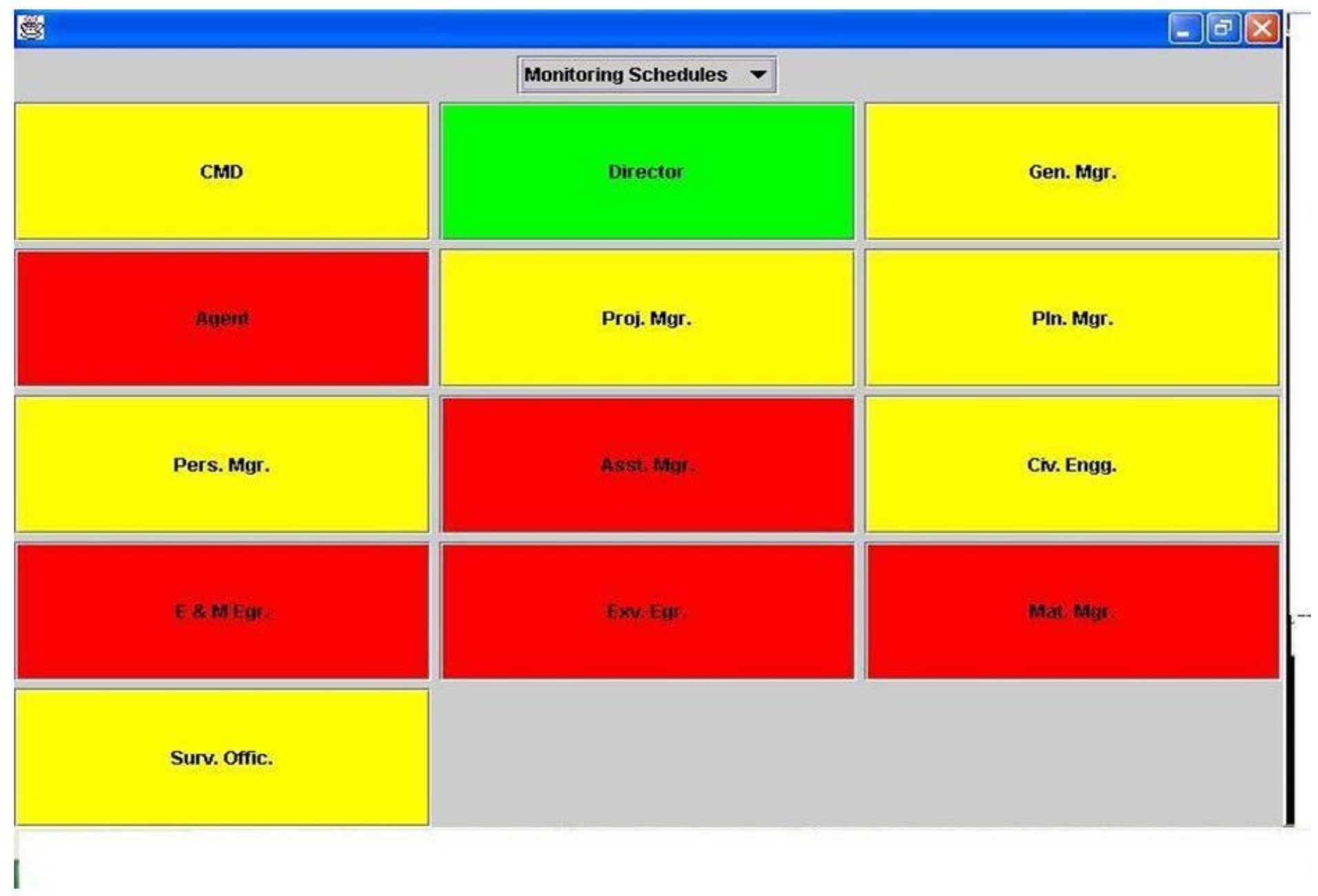

FOR A MONTH OF A PROJECT REVIEW $-\mathrm{RED}=\mathrm{Y}$, YELLOW=C, GREEN=N

\section{Figure 7}

shows model run of the program for different key tasks.

\section{Supplementary Files}

This is a list of supplementary files associated with this preprint. Click to download.

- GRPHICALABSTRACT.gif

- Table2.jpg

- Algorithmsofmodelprograms.docx 